\title{
TRANSPORT CONNECTIONS BETWEEN AIRPORTS AND INTERACTION OF AIRPORTS WITH OTHER TRANSPORTATION TYPES: AN IMPLEMENTATION IN ISTANBUL
}

\author{
DOI: 10.17261/Pressacademia.2018.922 \\ PAP- V.7-2018(75)-p.388-392
}

Mevlut Uzulmez ${ }^{1}$, Savas S. Ates ${ }^{2}$, Hasan Lik ${ }^{3}$, Tolga Kaya ${ }^{4}$

${ }^{1}$ Erciyes University, Faculty of Aeronautics and Astronautics, Aviation Management Department, Kayseri, Turkey. mevlutuzulmez@erciyes.edu.tr, ORCID: 0000-0002-4606-7468

${ }^{2}$ Anadolu University, Faculty of Aeronautics and Astronautics, Aviation Management Department, Eskisehir, Turkey. ssates@anadolu.edu.tr, ORCID: 0000-0003-2462-0039

${ }^{3}$ Anadolu University Faculty of Aeronautıcs and Astronautics, Eskisehir, Turkey. hlik@anadolu.edu.tr, ORCID: 0000-0002-5981-4223

${ }^{4}$ Anadolu University Faculty of Aeronautıcs and Astronautics, Eskisehir, Turkey. tolgakaya@anadolu.edu.tr, ORCID: 0000-0002-9250-1499

To cite this document

Uzulmez, M., Stes, S. S., Lik, H., Kaya, T. (2018). Transport connections between airports and interaction of airports with other transportation types: an implementation in Istanbul. PressAcademia Procedia (PAP), V.7, p.388-392.

Permemant link to this document: http://doi.org/10.17261/Pressacademia.2018.922

Copyright: Published by PressAcademia and limited licenced re-use rights only.

\section{ABSTRACT}

Purpose- Istanbul, the busiest city of Turkey, is having transportation problems because of the rapid population growth especially during the last 20 years. Main purpose of this study is to analyze the current passenger and freight relocation between Atatürk and Sabiha Gökçen Airport with railway, highway and seaway in İstanbul/TURKEY and to determine the possible effect of Ro-Ro and Ro-La models (WOXENIUS \& LUMSDEN, 1994).

Methodology- According to aim of this study, benchmarking which is one of the most common method of qualitative research has been implemented between transport types of Istanbul and London's airports (Kyrö, 2003). Data has been collected via released documentation of transportation authorities and in-depth analysis has been performed to clarify the meaningful information.

Findings- So that, Ro-Ro and Ro-La transportation models have been envisioned with the aim of reaching the desired low-cost and low-risk level.

Conclusion- Appropriate connection models between two airports have been discussed and on the purpose of improvement of system some recommendations have been made.

Keywords: Combined transportation, RO-RO, RO-LA transportation models, airport connections.

JEL Codes: L93, R41, L98.

\section{INTRODUCTION}

Relocation of people and cargoes quickly, safely, comfortably and economically has become an important need. Today, appropriate modes of transport have been developed to meet this basic transportation need. These modes are; road, railway, sea and inland waterway, airway and pipeline and information and communication lines. Parallel to economic growth, the population of Istanbul is rapidly increasing, while the metropolitan area is growing rapidly. In 1985, the population was about 6 million, and became over 13 million in the quarter century. In Istanbul, the usage of motor vehicles has increased rapidly due to intense urbanization, population growth and economic growth. Traffic congestion problem has reached to serious dimensions and serious adverse effects such as accident and exhaust emission problems have started to be occurred (Ulaşım Planlama Müdürlüğü, 2011).

In our country, $95.2 \%$ of the passenger transportation is done by highway. This rate is $89 \%$ in USA and $79 \%$ in EU countries. Highway usage rate in the freight forwarding area is around $76.1 \%$ in our country. This rate is $69.5 \%$ in USA and $45 \%$ in EU countries (Keçeci, 2018 ). However, railways are shown as the best alternative to highways in urban transport. However, the use of the suburban train has stopped after the High-Speed Train projects and Haydarpasa Train Station is not on operation for the time being. In contrast, Marmaray, Yenikapı-Haliç-Şişhane, Yenikapı-Aksaray and Levent-Rumeli Hisarüstü metro lines were opened in 2013 and 2015 respectively (Uysal, 2018). One of the strongest aspects of the Istanbul sea freight transportation is the population of 14 million and a transportation demand of 1.2 million between the two sides of the city. There is also the capacity to respond to this request with local government and private operators on their own (Çancı, 2015).

In the first part of the study, international and national identification of Ro-Ro and Ro-La transportation were provided. In the second part of the study, survey dimensions developed to measure the test system perception are explained. In the third part of the study, current status of transportation between airports in İstanbul was analyzed. Eventually, in light of information from analysis, some recommendations and a connection transportation model proposal have been made to develop the system. 


\section{LITERATURE REVIEW}

\section{Ro-Ro Transportation}

RO-RO loads are defined as loads that can cover all kinds of axles from railway carriages to helicopters and work machines and that can be stacked on the front and pulled down from the rear by vehicles (Zis \& Psaraftis, 2017). The idea of loading and transporting has been created by replacing wheeled cargo trailers to the ship by ramps to provide the roadway-sea route integrity. Therefore, the entry and exit of the cargo to and from the port are on the wheeled vehicles (Hülagü, 2007). One of the major factors in preferring RO-RO vessels is the fact that the goods produced in the factory allow the goods to be transported so fast by being loaded and unloaded only once in a carrier vehicle. In addition, goods can be transported more safely and faster than highway transportation (MdArof, 2018). The main principle is that load waits for the ship; The advantage of RO-RO transportation compared to other transportation methods is that it can be faster and more programmed in shorter time. To this end, RO-RO ships, which have been developed in distinct types, are also developing rapidly (Telle, 1987).

Moreover, some of Ro-Ro ships which developed countries have large aircraft carriers, , can be included in this class in terms of their use logic. Although there are many different technologies and uses, it is still possible to distinguish these ships by category (Aksoy, 2011). Firstly, RO-RO vessels can be categorized as two which are long distance vessels in open sea according to operation area and short-distance voyages in the inner sea and throat. After that, they are divided into 4 main categories such as cargo vessels, container vessels, bulk vessels, passenger vessels (Yıldırım, 2006).

\section{Ro-La Transportation}

The Ro-La concept consists of the abbreviation of two words, which is "Rollende Landstrasse" (in German language). This is the type of railway transport, the transport of trucks in private wagons is a question. This includes the transport of loaded trucks in the form of private railway transport. The trucks are loaded onto the wagons with a very simple loading system and are transported to desired point by trains (Hülagü, 2007). At their destination, they are unloaded from vessels and they are put on their planned road by trucks again. Ro-La transport is widely used in developed country railways and is considered to be one of the best transportation type of the future.

The most important advantage of RO-LA transportation is; to relieve road traffic and reduce the problems experienced in transit between countries. The trucks can continue their way after they have been taken from the wagons. Although railway transport is used, the most advantageous side of road transportation, door-to-door transportation, can still be maintained. Moreover, while trucks are being transported in wagons, vehicle drivers also travel in private wagons and have the opportunity to rest. The main disadvantage of the Ro-La transport is that the empty weights of the trucks are regarded as loads carried by the railway (Almeida \& Raffo, 2015). Trucks that can carry heavy loads are also heavy. The total transportation cost is calculated accordingly, which increases the transportation cost (Jaržemskis \& Jaržemskienė, 2017).

\section{FINDINGS AND DISCUSSION}

\section{Current Status of Transportation Between Airports in İstanbul}

Since Ataturk Airport is an airport inside the city, it is possible to reach to the airport by using many transportation methods. Direct access to the airport is possible using railway and highway. Transportation by sea is possible by road and rail links. The most preferred mode of transportation is the metro because this mode does not include risk of traffic and provide direct access (Yavaş, 2013). However, it is seen that the use of private vehicles is very intense in İstanbul, and that public transportation is also inadequate in terms of population and that roads are also very important for transportation to the airport.

On the Anatolian side of Istanbul; Sabiha Gökçen Airport which is located at Pendik district plays a significant role in the process of development. The airport is $40 \mathrm{~km}$ away from Kadikoy, $12 \mathrm{~km}$ from Pendik and $50 \mathrm{~km}$ from Taksim. In terms of number of passengers, Sabiha Gökçen Airport maintains its position after Antalya and Ataturk airport (ISG, 2018). Moreover, it is holding its position as 3 'th airport in Turkey in terms of the amount of cargo carried. On the other hand, the share of freight transport is considerably lower than passenger transport.

However, Sabiha Gökçen Airport is not preferred by the residents of Fatih Sultan Mehmet Bridge or the Bosporus Bridge area because of the high traffic density between the two sides. It is being used more intensely by the residents of the Anatolian side. The presence of an alternative airport for Ataturk Airport in Istanbul which hosts a population of 14 million people is important not only in response to the needs of a large population, but also because it eliminates the additional traffic burden that can be caused by reaching airport between the two sides. This situation also contributes to the widespread use of air transportation by making it easier for people to access the airport. As a matter of fact, according to a survey conducted among the passengers using the airport in 2006, the majority of the passengers who prefer the airport live (91\%) or work (73\%) in the Anatolian side. It is presented as the most important reason why the airport is preferred because it is close to the place where they live or work. 76\% of the people living on the Anatolian side of the survey indicated that Sabiha Gökçen Airport has increased the frequency of using air transportation. The fact that there are not many problems such as delays in Sabiha Gökçen Airport, since it has lower passenger traffic compared to the delays experienced by landings and departures due to the intensity of the flights at Atatürk Airport.

The transportation between the two airports in Istanbul is not efficient enough both in terms of time and cost. For example, if you get a taxi between two airports, it will cost more than $\mathbf{3 0}$ dollars. Despite the advantages of current modes of transport, it is impossible to be successful in single-passenger transport between two airports, even if a passenger living in Anatolia is not able to go to Atatürk Airport with a single vehicle at a fast and low cost.

Today, transportation connections between two airports are as follows (ISG, 2018): 
- The road which chooses the sea journey can go to Kadıköy with E11 IETT buses or Havataş buses and get to Bakırköy sea buses from here. The Ataturk Airport is a taxi ride from Bakırköy.

- Secure Drive Shuttle service allows you to travel between two airports quickly and comfortably.

- It can be reached from Sabiha Gökçen Airport using Havataş - Taksim and Taksim - Havataş AHL buses.

Since there is no cargo flow, no specific line for cargo transfer between the two airports. However, this kind of transfer will be needed with the construction of the third airport. In order to fill this void, some governmental actions ought to be taken. Cargo and passenger transportation between two airports will lead high time and cost benefit to both to passenger or freight forwarders.

\section{PROPOSAL OF A MODEL FOR CONNECTION BETWEEN AIRPORTS}

\section{Halkalı Train Station-Ataturk Airport: Ro-La and Passenger Connection Proposal}

Atatürk Airport is Turkey's largest and busiest airport. However, at present size it cannot meet the demand. For this and many other reasons it has been decided to build a third airport in Istanbul and the construction of this airport continues. Then, all operations will be transferred to the third airport. Once the third airport construction is over, Atatürk Airport might be considered as "cargo airport". Halkalı Terminal is Turkey's international railway traffic center with a large container storage areas and customs which is on the European side of Istanbul, 27 kilometers from the railway-Kapıkule. It is one of 19 logistic centers determined by TCDD throughout the country. Once the projects are completed, it will be the destination of the European side the Marmaray Suburban Trains and the high-speed trains to Istanbul (Uysal O. , 2018).

Halkalı Train Station is a point that TCDD wants to use as a starting point for RO-LA transportation. A major contribution to the country is expected to be the reduction of road traffic, better use of existing capacity, security, noise abatement, environmental and urban development, low personnel expenditures, savings in road tax, reduction of transit distress at border ports and customs facilities. With the participation of representatives of the TCDD, Bulgarian, Romanian and Yugoslavian Railway Administrations, the meeting of the SERG WG 3 Combined Transportation Working Group held in Istanbul in July 2005 concluded that RO-LA transport should be carried out in three routes (TCDD, 2014).

\section{- Route 1: $2119 \mathrm{Km}$}

Halkalı (Turkey) / Bulgaria / Romania / Hungary - Wels (Austria)

- Route 2: $1962 \mathrm{Km}$

Halkalı (Turkey) / Bulgaria / Serbia and Montenegro / Croatia / Slovenia / Wels (Austria)

- Route 3: $1840 \mathrm{Km}$

Halkalı (Turkey) / Bulgaria / Serbia and Montenegro / Hungary / Wels (Austria)

Marmaray, one of the largest transportation projects of the Republican history, was opened on 29 October 2013. There are 3 underground stations (Üsküdar, Sirkeci and Yenikapi) and 2 overhead stations (Ayrılıkçeşmesi, Kazlıçeşme) station. The total travel time between the Ayrılıkçeşmesi and Kazlıçeşme is 18 minutes. Yeşilköy Railway Station which is located in Halkalı-Sirkeci suburban line is located (Fig.1.) just below Atatürk Airport and it is very easy to reach to Halkalı railway station. If we consider that Atatürk Airport will be turned into a cargo airport in the future and that the transfer of the railway between Yeşilköy Train Station and Ataturk Airport is started, we will be able to keep the highways of İstanbul less busy, the railway will be able to become more efficient. In this context, it would be more logical to make RO-LA transportations at night, in order to keep passengers busy. The cargo area (Fig.2.) under the runway 03 seen in the master plan and the area reserved for future expansion are adjacent to Yeşilköy Train Station. By joining these two zones into the cargo area, a large area will be created, and RO-LA transport and air cargo transportation will be easily achieved bidirectionally as it is close to the train station.

Figure 1: Location of Airport and Yeşilköy Train Station

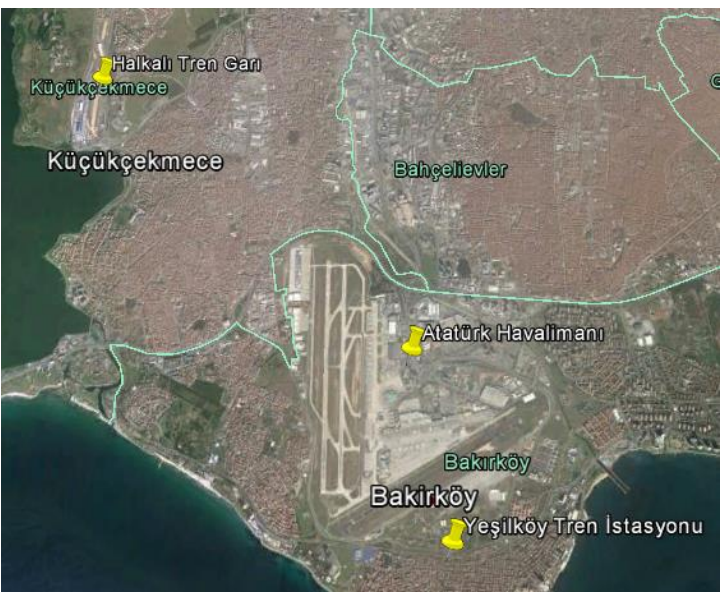

\section{Figure 2: Cargo Area of Atatürk Airport}

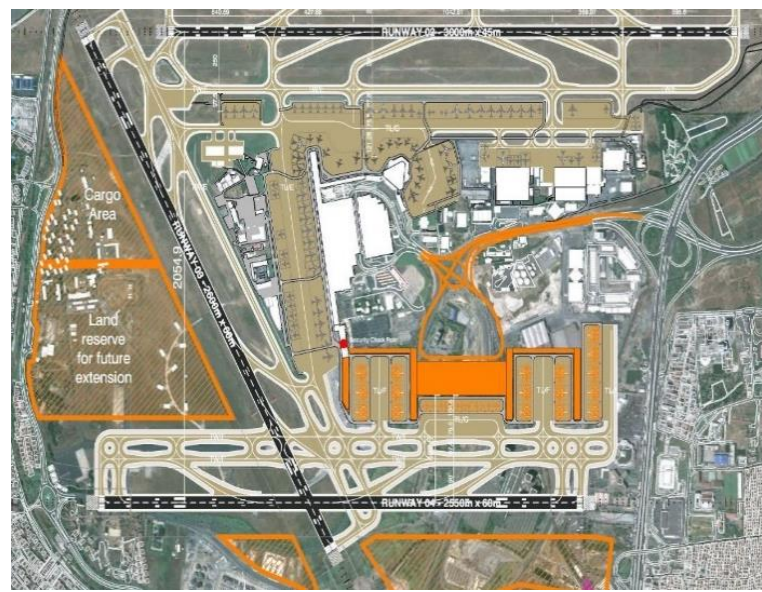




\section{Pendik Train Station-Sabiha Gökçen Airport Connection}

The largest of railway system, the Marmaray Project will connect Asian and European sides of with a Tunnel under the Bosporus; both the passenger and the load will be able to be transported. The existing suburban line on both sides of the Bosporus will be fully cured from Gebze in Asia to the vicinity of Halkali in Europe. All the improvements and new lines will be $76.5 \mathrm{~km}, 13.6 \mathrm{~km}$ will pass under the Bosporus with the tube tunnel. The project consists of three components: "Bosporus passage, improvement of existing pipeline and procurement of passenger wagons". The total cost of the project is estimated at US \$ 3 billion (Ulaşım Planlama Müdürlüğü, 2011).

Pendik - Sabiha Gökçen Airport suburban line is planned to meet the journeys to Sabiha Gökçen Airport and at the same time it will be a part of Marmaray line. Thus, the passengers coming from the Marmaray line and Kadıköy - Kartal - Kaynarca metro line will be integrated at Pendik station and can access Sabiha Gökçen Airport easily. The length of this line will be $8.2 \mathrm{~km}$ (Ulaşım Planlama Müdürlüğü, 2011, p. 338).

\section{Transportation Network Between Gebze-Halkalı Train Stations}

International and long-distance trains operate on the TCDD railway line. The suburban line is operated by TCDD on the route between SirkeciHalkalı and Haydarpasa-Gebze both sides of the city along the Marmara Sea in Istanbul. Sirkeci - Halkalı consists of $30 \mathrm{~km}$ long and 18 stations; whereas Haydarpaşa - Gebze has 42 stations and 25 stations. Travel times are 48 and 65 minutes respectively. The power supply system is AC $25 \mathrm{kV} 50 \mathrm{~Hz}$ Catenary (Ulaşım Planlama Müdürlüğü, 2011, p. 76 ). 37 stations on this line will be rebuilt or replaced with Marmaray. The current line of TCDD will be improved within the scope of the project. On European route from Halkalı to Asia near Gebze, the existing twotrack route will be three rails and $1,4 \mathrm{~km}$ of the whole $76.5 \mathrm{~km}$ will go underground.

It is planned that there will be 38 stations between Gebze-Halkalı and approximately 105 minutes of journey. There is a distance of about 3 minutes between two stations. If a person gets on Yeşilköy Train is thought to have passed about 30 stops to reach Pendik Station, it will be the same transportation time of about 1 hour 30 minutes however this type of transportation will be provided at much less cost.

\section{Pendik Port-Sabiha Gökçen Airport Ro-Ro Connection}

The port of Pendik has a parking area of 1000 trailers and a railway connection in a use area of $175.000 \mathrm{~m} 2$. UN RO-RO has cost USD 35 million including land price. The port, which is outside the city center of Istanbul, removes heavy truck and trailer traffic from the city (U.N. RO-RO, 2018). Pendik Ro-Ro harbor and Sabiha Gökçen Airport are approximately $12 \mathrm{~km}$ by road and there is convenient road transportation connecting the two locations. Using this road transportation, load circulation will be provided by carrying out consolidation work between air cargo and Ro-Ro cargo.

Connection proposal map (Fig.3.) is shown according to all above information. This connection will help both transportation and traffic jam while decreasing general cost price.

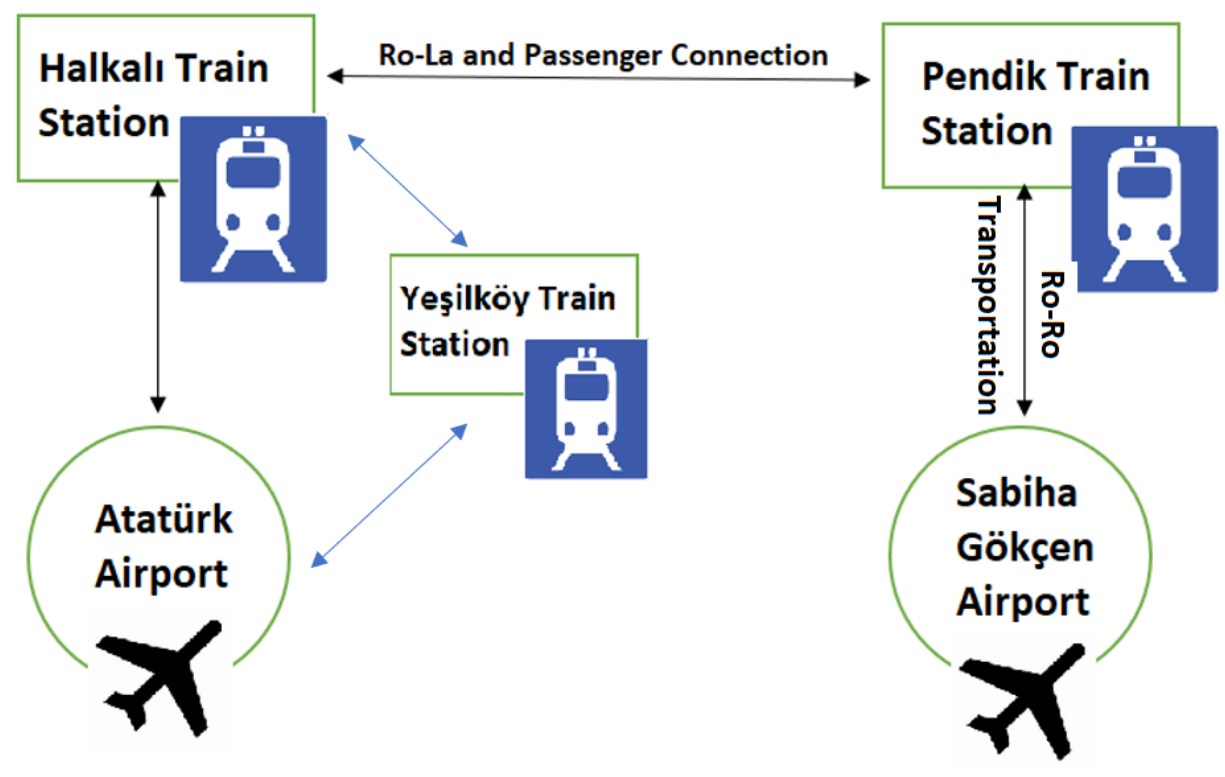

\section{CONCLUSION}

With the increasing cargo and passenger traffic, need of new type of transportation has become more obvious. Especially in a city such as Istanbul, connection points to another with railway may help traffic to lower its congestion. Since there is no connection between Atatürk and Sabiha Gökçen Airport, it is a must to find a way to speed up travel time and decrease the cost. In order to achieve these goals, we have suggested a transportation flow model. This model has three part, the first part is that connection of Atatürk Airport to Halkalı Train Station via Yeşilköy Train station. Second part is Connection Sabiha Gökçen Airport to Pendik Train Station by Ro-Ro transportation. Third and the final part is connection these two points (Halkalı and Pendik Train Station) to each other with Ro-La and Passenger Connection. 
As a result of this flow model, it is foreseen that there will be more comfortable, and cost/time efficient journey will take place for both passenger and freight forwarder. Development of railway system between these points will increase unit revenue and country's prestige in terms of -multimodal \&intermodal transportation. In the future study, it is recommended to reorganize the model for the İstanbul Third Airport and make informative calculation about the cost of current model to figure out approximate balance sheet.

\section{REFERENCES}

Aksoy, S. (2011). RO-RO terminalleri için simülasyon modellemesi. İstanbul: İstanbul Teknik Üniversitesi.

Almeida, M., Raffo, G. (2015). Nonlinear control of a TiltRotor UAV for load transportation. Belo Horizonte: IFAC-PapersOnLine.

Çancı, M. (2015). İstanbul’da deniz ulaşımının geleceğinin değerlendirilmesi. İstanbul: Okan Üniversitesi İktisadi ve İdari Bilimler Fakültesi.

Hülagü, S. E. (2007). RO-RO taşımacılığı ve Türkiye'deki uygulamalar. İstanbul: İstanbul Teknik Üniversitesi.

ISG. (2018, 05 16). About ISG. https://www.sabihagokcen.aero: https://www.sabihagokcen.aero/corporate-info/about-isg adresinden alındı ISG. (2018, 050 16). Sabiha Gökçen Havalimanı sitesi. http://www.sabihagokcen.aero: http://www.sabihagokcen.aero/flashes/UlasimHaritasiTR.swf adresinden alındı

Jaržemskis, A., Jaržemskienè, I. (2017). Comparison of rail freight transportation markets in Lithuania and Poland. Vilnius : Procedia Engineering.

Keçeci, A. (2018, 05 15). Türkiye'de karayolu taşımacılığı. Retrieved from mfa.gov.tr: http://www.mfa.gov.tr/turkiye_de-karayolutasimaciligi-.tr.mfa

Kyrö, P. (2003). Revising the concept and forms of benchmarking. BENCHMARKING: AN INTERNATIONAL JOURNAL, 10(3), $210-225$.

MdArof, A. (2018). Decision making model for Ro-Ro short sea shipping operations in Archipelagic Southeast Asia. Kuala Lumpur: The Asian Journal of Shipping and Logistics.

TCDD. (2014, 05 17). tcdd-rola-tasimaciligina-hazirlaniyor. Tcdd.gov.tr: http://www.tcdd.gov.tr/tcdd-rola-tasimaciligina-hazirlaniyor+h117 adresinden alındı

Telle, J. (1987). Design of RO-RO ships and ferries. DNV paper series.

U.N. RO-RO. (2018, 05 20). İstanbul Pendik. unroro.com.tr: http://www.unroro.com.tr/limanlar/tr/9/istanbul-pendik/51 adresinden alındı

Ulaşım Planlama Müdürlüğü. (2011). istanbul metropoliten alanı kentsel ulaşım ana planı. İSTANBUL: Ulaşım Planlama Müdürlüğü.

Ulaşım Planlama Müdürlüğü. (2011). İstanbul Metropoliten Alanı Ulaşım Planlama Müdürlüğü. Giriş bölümü. İstanbul: Ulaşım Planlama Müdürlüğü.

Uysal, M. (2018, 05 15). Raylı sistem inşaatları Retrieved from İstanbulunmetrosu.com: http://www.istanbulunmetrosu.com/RayliSistemInsaatlari.aspx

Uysal, O. (2018, 05 17). Halkalı Terminali. Retrieved from tr.railturkey.org: https://tr.railturkey.org/2015/03/10/halkali-terminali-2/

Woxenius, J., Lumsden, K. (1994). System and functional requirements for RORO cassettes in multimodal transport. RoRo 94 (s. 1-10). Gothenburg,Sweden.: BML Business Meetings Ltd.

Yavaş, V. (2013). Lojistik merkezlerin havayolu ulaştırması yönlü analizi: Türkiye için bir uygulama. İzmir: Dokuz Eylül Üniversitesi.

Yıldırım, S. (2006). RO-RO taşımacılığında yer seçimi problemine yönelik bir çözüm geliştirilmesi ve İstanbul ili için uygulanması. istanbul: Yıldız Teknik Üniversitesi, Fen Bilimleri Enstitüsü.

Zis, T., Psaraftis, H. (2017). The implications of the new sulphur limits on the European Ro-Ro sector. Lyngby: Transportation Research Part D: Transport and Environment. 